\title{
EHMTI-0123. New-onset headaches heralding demyelination
}

\author{
M Vinjam*, M Khalil, A Al-Din \\ From 4th European Headache and Migraine Trust International Congress: EHMTIC 2014 \\ Copenhagen, Denmark. 18-21 September 2014
}

\section{Background}

Headache is a rare presenting demyelinating feature in people who go on to develop multiple sclerosis (MS). It has been suggested that approximately $2 \%$ of MS patients present with headache. There has been a debate whether MS patient group are at higher risk of developing headaches. We are not aware of any case reports where an occipital headache heralds first or recurrent high cervical cord demyelinating lesion.

\section{Aim}

To report headache characteristics in patients whose headache was the main presenting symptom of MS

\section{Method}

We prospectively collected data from patients who were referred to the MS clinic with new onset headaches who were found to have first demyelinating episode or MS relapse over the last 12 months. Magnetic Resonance Imaging (MRI) scans were reviewed for relevant demyelinating lesions.

\section{Results}

We identified four patients with evidence of demyelination whose main symptom was new onset-headache (three with stabbing occipital headache and one with thunderclap headache) and were found to have relevant abnormal physical examination.

Of these four patients, three had demylinating plaque at C1-C2 segments. In 2 out of 4 cases, headache represented the first demyelinating episode.

\section{Conclusion}

Cervical spinal cord is a heavily myelinated structure, demyelinating plaques could induce nociceptive inflow by affecting the trigemino-cervical complex.

It is the traditional thinking that headaches are an unlikely presentation of a demyelinating episode, however detailed headache history coupled with appropriate examination and investigations could potentially reveal conditions which requires totally different therapeutic approach from the common primary headache disorders.

No conflict of interest.

Published: 18 September 2014

doi:10.1186/1129-2377-15-S1-D33

Cite this article as: Vinjam et al.: EHMTI-0123. New-onset headaches

heralding demyelination. The Journal of Headache and Pain 2014

15(Suppl 1):D33.
Submit your manuscript to a SpringerOpen ${ }^{\circ}$ journal and benefit from:

- Convenient online submission

- Rigorous peer review

- Immediate publication on acceptance

- Open access: articles freely available online

- High visibility within the field

- Retaining the copyright to your article

Submit your next manuscript at $\mathbf{p}$ springeropen.com

\section{SpringerOpen ${ }^{\circ}$}

C 2014 Vinjam et al; licensee Springer. This is an Open Access article distributed under the terms of the Creative Commons Attribution License (http://creativecommons.org/licenses/by/2.0), which permits unrestricted use, distribution, and reproduction in any medium, provided the original work is properly cited. 